\title{
Poly I:C accelerates ovum transport in the rabbit by a prostaglandin-mediated mechanism
}

\author{
M. J. K. Harper, Catherine J. Norris, W. E. Friedrichs and A. Moreno
}

Department of Obstetrics and Gynecology, The University of Texas, Health Science Center at San Antonio, 7703 Floyd Curl Drive, San Antonio, Texas 78284, U.S.A.

\begin{abstract}
Summary. Administration of poly I:C (1 mg/kg i.v.) to rabbits $24 \mathrm{~h}$ after an ovulating injection of hCG caused accelerated ovum transport; only $30 \%$ of the ova were still found in the oviducts $24 \mathrm{~h}$ later compared with $79 \%$ of ova in control animals. This action of poly $\mathrm{I}: \mathrm{C}$ was prevented by concomitant administration of indomethacin. Poly $\mathrm{I}: \mathrm{C}(0.5 \mathrm{mg} / \mathrm{kg}$ i.v. $)$ given to anaesthetized rabbits produced significantly increased levels of prostaglandins (PGs) $E$ and $F$ in uterine vein blood up to $2 \mathrm{~h}$ later. Production of PGs by lung, oviduct and myometrium was unaffected $2 \mathrm{~h}$ after poly I:C administration, but production of both PGE and PGF by endometrium was significantly elevated at the same time. Metabolism of PGs by cytosols of lung, oviduct and uterus was inhibited to various degrees at $2 \mathrm{~h}$ after poly I:C ( $1 \mathrm{mg} / \mathrm{kg}$ i.v.), but by $4 \mathrm{~h}$ after treatment this process was reduced to $70-80 \%$ of pretreatment values. It is concluded that poly $\mathrm{I}: \mathrm{C}$ accelerates ovum transport through the oviduct by a PG-mediated mechanism, and that elevated levels of PGs in oviduct are due to inhibition of metabolism of PGs.
\end{abstract}

\section{Introduction}

Poly I:C is a complex of polyriboinosinic and polyribocytidylic acids which is capable of stimulating interferon production following injection of $1 \mu \mathrm{g} /$ animal intravenously (i.v.) to rabbits (Field, Tytell, Lampson \& Hilleman, 1967), of $10 \mathrm{mg} / \mathrm{kg}$ intraperitoneally (i.p.) to mice (Takehara, 1977) and $2000-4000 \mu \mathrm{g} / \mathrm{kg}$ i.v. to patients with cancer (Field et al., 1971).

It has been reported that poly $I: C$ and bacterial endotoxin show similarities in interferon-stimulating mechanisms and toxic properties (Absher \& Stinebring, 1969). Lead acetate heightens the lethal reactivity to endotoxin (Suter, 1964) and to poly I:C in mice (Absher \& Stinebring, 1969). Intravenous administration of poly I:C at doses of 0.5 or $50 \mu \mathrm{g} / \mathrm{kg}$ to rabbits (Lindsay, Trown, Brandt \& Forbes, 1969) or of $25 \mu \mathrm{g} / \mathrm{kg}$ i.v. to man (Field et al., 1971; Guggenheim \& Baron, 1977; Freeman et al., 1977) elevates body temperature. Other adverse reactions are chills, myalgias, nausea, vomiting and diarrhoea, the severity depending on the dose (Field et al., 1971; Cornell, Smith, Cornwell, Burke \& McIntyre, 1976; Guggenheim \& Baron, 1977; Freeman et al., 1977). Similar reactions may occur after administration of endotoxin (Griesman \& Hornick, 1973) or prostaglandin (Bergström, Dunér, Von Euler, Pernow \& Sjövall, 1959; Carlson, Ekelund \& Orö, 1968; Karim \& Filshie, 1970). The increased PGE production by cultured human synovial or foreskin fibroblasts in the presence of poly I:C is blocked by the addition of cortisol (Yaron et al., 1977).

Poly I:C $(1 \mu \mathrm{g} / \mathrm{kg}$ ) given subcutaneously (s.c.) to rabbits on Days 8 and 9 or Days 11 and 12 of pregnancy causes resorption of 80 and $61 \%$, respectively, of the implantation sites (Adamson, Fabro, Homan, O'Gara \& Zendzian, 1969) and endotoxin (5 or $10 \mu \mathrm{g} / \mathrm{kg}$ i.v.) has 
similar actions when given on Day 8 to pregnant rabbits (Valenzuela, Harper \& Magnasco, 1978; Harper, Valenzuela, Hodgson \& Siler-Khodr, 1979). Endotoxin also prevents implantation in the rabbit, if given on Day 4 (Harper et al., 1979) and causes accelerated ovum transport if given between 18 and $38 \mathrm{~h}$ after injection of hCG (Harper, Valenzuela \& Hodgson, 1978; Harper, Weinberg, Moreno \& Friedrichs, 1980c). This latter action was shown to be prostaglandin-mediated and reversible by indomethacin (Harper et al., 1978).

An agent that could be used as a post-coital contraceptive would have obvious therapeutic value. Endotoxin cannot be used therapeutically but the present experiments were designed to examine whether poly I:C would alter ovum transport in rabbits and, if so, the probable mechanism of action.

\section{Materials and Methods}

New Zealand white rabbits weighing $>3 \mathrm{~kg}$ were isolated in a controlled environment with $14 \mathrm{~h}$ light $/ 24 \mathrm{~h}$. They had been caged individually for the previous 21 days after receiving an i.v. injection of 100 i.u. hCG (APL: Ayerst Laboratories, New York) at the breeder's rabbitry. At the start of the experiment, the rabbits received a second i.v. injection of hCG to induce ovulation and pseudopregnancy. At $48 \mathrm{~h}$ after the ovulatory stimulus there is no difference in the rate of ovum transport between naturally mated rabbits and those given this dose of $\mathrm{hCG}$ (Hodgson \& Pauerstein, 1976).

\section{Experiment 1}

To study ovum transport, groups of 4-6 rabbits received graded doses of poly I:C (Sigma Chemical Co., St Louis, Missouri) dissolved in saline $(9 \mathrm{~g} \mathrm{NaCl} / 1)$, or vehicle alone, i.v. into the marginal ear vein at $24 \mathrm{~h}$ after the $\mathrm{hCG}$ injection. The rabbits were killed $24 \mathrm{~h}$ later by an overdose of pentobarbitone sodium (Diabutal: Diamond Labs, Des Moines, Iowa) and the location of the ova in the genital tract was determined by flushing separately the oviduct, the uterine horns and the vagina (Valenzuela, Ross, Hodgson, Harper \& Pauerstein, 1977). Two additional groups of rabbits were treated similarly except that one group received only vehicle at $24 \mathrm{~h}$ after the hCG, while the other received poly I:C (1 mg/kg i.v.) and indomethacin (Merck, Sharp and Dohme, Rahway, New Jersey: $10 \mathrm{mg} / \mathrm{kg}$ s.c.) at the same time.

\section{Experiment 2}

Three additional groups of rabbits (4-7/group) were injected with 100 i.u. hCG to examine changes in uterine vein blood levels of prostaglandins (PGs). At $22 \mathrm{~h}$ after hCG the rabbits were anaesthetized with pentobarbitone sodium and subjected to mid-ventral laparotomy. One uterine vein was catheterized with polyethylene tubing (o.d. $0.15 \mathrm{~cm}$, and i.d. $0.086 \mathrm{~cm}$; Intramedic: Clay Adams, Parsippany, New Jersey). Heparin (1500 units, Upjohn Co., Kalamazoo, Michigan) was injected through the catheter and a period of stabilization allowed before a control blood sample was withdrawn. At $24 \mathrm{~h}$ after hCG, $0.5 \mathrm{mg}$ poly I:C/kg dissolved in saline, or vehicle alone, was injected i.v. and blood samples were taken $0.5,1,2,3,4$ and $6 \mathrm{~h}$ later. The blood was collected into a heparinized syringe containing enough indomethacin to give a final concentration of $>10 \mu \mathrm{g} / \mathrm{ml}$. The plasma was separated by centrifugation ( $500 \mathrm{~g}$ for $20 \mathrm{~min}$ ) and frozen at $-20^{\circ} \mathrm{C}$ until assay for prostaglandins $F$ and $E$. The PGs were extracted, chromatographed on silicic acid columns and measured by methods previously described (Harper et al., 1978) and modified as follows. The final dilutions of the antibody were $1: 1600$ and 1:32 for the antisera to PGF and PGE respectively. To each assay tube (Biovial: Beckman Instruments Inc., Houston, Texas) was added $0.3 \mathrm{ml}$ phosphate buffered saline (PBS) containing 
$0.3 \%$ bovine gamma globulin (BGG) and 5000 c.p.m. of the appropriate labelled PG diluted in $0.1 \mathrm{ml}$ PBS-BGG. The samples were incubated at $4^{\circ} \mathrm{C}$ for $4 \mathrm{~h}$ before addition of $0.5 \mathrm{ml} 65 \%$ polyethylene glycol in distilled water containing $2 \mathrm{mM}^{-\mathrm{CaCl}_{2}}$ at $\mathrm{pH} 7.4$. The tubes were centrifuged at $20000 \mathrm{~g}$ for $30 \mathrm{~min}$ at $4^{\circ} \mathrm{C}$. After removal of the supernatant $0.1 \mathrm{~N}-\mathrm{NaOH}$ was added to dissolve the pellet, which was processed as described previously. The amount of non-specific binding was unchanged from that seen when separation of bound and free PGs was effected by precipitation with a second antibody. The inter- and intra-assay coefficients of variation were, respectively, 9.8 and $10.7 \%$ for PGF and 5.0 and $11.6 \%$ for PGE.

\section{Experiment 3}

Experiments were done to examine whether poly I:C caused changes in PG synthesis or metabolism or both. To study synthesis two groups of rabbits were given 100 i.u. hCG i.v. and then injected with vehicle or poly I:C $(1 \mathrm{mg} / \mathrm{kg})$ i.v. $24 \mathrm{~h}$ later. Both groups were killed $2 \mathrm{~h}$ after this injection and samples of endometrium (pooled from both uterine horns), myometrium and lung, and both oviducts were removed. Thus, each animal provided one endometrial and one lung sample, and two pieces of myometrium and two oviducts. The tissues were kept in Tyrode's solution at $4^{\circ} \mathrm{C}$ during preparation. The tissues were washed three times with Tyrode's solution $\left(154 \mathrm{~mm}-\mathrm{NaCl}, 2.68 \mathrm{~mm}-\mathrm{KCl}, 0.98 \mathrm{~mm}-\mathrm{MgSO}_{4}, 11.9 \mathrm{~mm}-\mathrm{NaHCO}_{3}, 1.8 \mathrm{~mm}-\mathrm{CaCl}_{2}\right.$ and 5.55 mM-dextrose) and then placed in $1 \mathrm{ml}$ of the same solution in polypropylene tubes (Falcon, Oxnard, California) bubbled with $95 \% \mathrm{O}_{2}: 5 \% \mathrm{CO}_{2}$ and incubated for $1 \mathrm{~h}$ at $37^{\circ} \mathrm{C}$. After incubation, the tissues were removed, blotted, weighed and placed in $1 \mathrm{ml} 4 \mathrm{~N}-\mathrm{NaOH}$ for determination of protein content by the method of Lowry, Rosebrough, Farr \& Randall (1951). The incubation medium was acidified to $\mathrm{pH} 4.5$ with cold acetate buffer and the PGs were extracted by two additions of $4 \mathrm{ml}$ ethyl acetate (analytical grade, redistilled). The samples were then treated as described above for measurement of PGF and PGE by radioimmunoassay.

\section{Experiment 4}

To study metabolism 4 other groups of rabbits were given 100 i.u. hCG i.v. After $24 \mathrm{~h}$ two groups received vehicle i.v. and the other two, poly I:C (1 mg/kg i.v.). Rabbits in one control and one treated group were killed $2 \mathrm{~h}$ later $(26 \mathrm{~h}$ after hCG) and the others $4 \mathrm{~h}$ later $(28 \mathrm{~h}$ after hCG). Samples of lung, uteri and oviducts were rapidly removed and processed for preparation of a cytosolic fraction (100 $000 \mathrm{~g}$ supernatant) containing 15-hydroxyprostaglandin dehydrogenase (EC 1.1.1. 141) and $\Delta^{13}$-reductase. The chemicals and preparation of the enzyme fraction were exactly as described by Bodkhe \& Harper (1979). The incubation conditions and assays were as described by Bodkhe \& Harper (1979) with the following modifications. The incubation mixture contained $2 \mathrm{mM}-\mathrm{NAD}^{+}, 2 \mu \mathrm{g}$ of the appropriate unlabelled PG, about 40000 c.p.m. of the appropriate labelled PG (representing approximately 126 pg PGE-2 and 85 pg PGF-2 $\alpha$ ) and 1 $\mathrm{ml}$ of the enzyme preparation in $44 \mathrm{mM}$-Tris- $\mathrm{HCl}$ buffer containing various concentrations of protein depending on the tissue. The incubations, in a Dubnoff metabolic shaker, were at $37^{\circ} \mathrm{C}$ for $2 \mathrm{~min}$ for lung tissue, and 15 and $30 \mathrm{~min}$ for PGE-2 and PGF-2 $\alpha$, respectively, for both uterus and oviduct.

The results of the radiometric assay for PGE-2 and PGF-2 $\alpha$ metabolism were corrected for procedural losses, non-enzymic conversion (use of boiled cytosol) and loss of one tritium atom during metabolism and then calculated as $\mathrm{pmol} / \mathrm{mg}$ cytosolic protein. Statistical comparisons were effected by analyses of variance, followed by a Student-Newman-Kuels test (Sokal \& Rohlf, 1969), linear regression analysis (Sokal \& Rohlf, 1969) or $\chi^{2}$ test with Yates's correction. 


\section{Results}

\section{Experiment 1}

Poly I:C administered to rabbits at $24 \mathrm{~h}$ after hCG caused accelerated transport of ova from the oviduct during the next $24 \mathrm{~h}$, when the dose was $0.05 \mathrm{mg} / \mathrm{kg}$ or greater (Table 1). At this time the majority of ova recovered in control animals are still in the oviduct, and the percentage not recovered is low. The figures recorded for the control group are pooled data obtained from 4 control groups of rabbits killed at different times over a 5-month period. The percentage of ova removed from the oviducts in these different groups ranged from 76 to $84 \%$. Since the values did not differ significantly, the results from all 4 groups have been pooled (Table 1). There was little difference in the degree of acceleration of transport caused by the different doses of poly I:C; 1 $\mathrm{mg} / \mathrm{kg}$ seemed to be marginally more effective as judged by the percentage of ova not recovered from the tract, which is considered to be due to expulsion to the exterior.

Complete reversal of the action of poly $\mathrm{I}: \mathrm{C}$ on ovum transport was achieved by the concurrent administration of a single dose of indomethacin (Table 2).

Table 1. Effect on ovum transport in rabbits killed $48 \mathrm{~h}$ after hCG and $24 \mathrm{~h}$ after i.v. treatment with poly I:C

\begin{tabular}{cccccc}
\hline $\begin{array}{c}\text { Dose } \\
(\mathrm{mg} / \mathrm{kg})\end{array}$ & $\begin{array}{c}\text { No. of } \\
\text { rabbits }\end{array}$ & $\begin{array}{c}\text { No. of } \\
\text { CL }\end{array}$ & $\begin{array}{c}\text { No. of ova in } \\
\text { oviducts } \\
(\%)\end{array}$ & $\begin{array}{c}\text { No. of ova in } \\
\text { uterus/vagina } \\
(\%)\end{array}$ & $\begin{array}{c}\text { No. of ova } \\
\text { missing } \\
(\%)\end{array}$ \\
\hline Control & 17 & 179 & $142(79)$ & $11(6)$ & $26(15)$ \\
0.001 & 4 & 38 & $31(82)$ & $11(3)$ & $6(16)$ \\
0.005 & 4 & 38 & $28(74)$ & $7(18)$ & $4(8)$ \\
0.050 & 4 & 27 & $13(48)^{* *}$ & $0(0)$ & $14(52)$ \\
0.250 & 4 & 35 & $13(37)^{* * *}$ & $5(14)$ & $17(49)$ \\
0.500 & 6 & 52 & $25(48)^{* * *}$ & $3(6)$ & $24(46)$ \\
1.000 & 6 & 47 & $14(30)^{* * *}$ & $1(2)$ & $32(68)$ \\
\hline
\end{tabular}

** $P<0.01 ;{ }^{* * *} P<0.001$ compared with control values ( $\chi^{2}$ with Yates' correction).

Table 2. Reversal of the effects of poly I :C (1 mg/kg i.v., given at $24 \mathrm{~h}$ after hCG) on ovum transport in rabbits killed $48 \mathrm{~h}$ after hCG

\begin{tabular}{lcccc}
\hline \multicolumn{1}{c}{ Treatment } & $\begin{array}{c}\text { No. of } \\
\text { rabbits }\end{array}$ & $\begin{array}{c}\text { No. of } \\
\text { CL }\end{array}$ & $\begin{array}{c}\text { No. of ova in } \\
\text { oviducts } \\
(\%)\end{array}$ & $\begin{array}{c}\text { No. of ova in } \\
\text { uterus/vagina }\end{array}$ \\
\hline Control & 17 & 179 & $142(79)$ & 11 \\
Poly I:C & 6 & 47 & $14(30)^{*}$ & 1 \\
$\begin{array}{l}\text { Poly I:C } \\
\text { + indomethacin }\end{array}$ & 6 & 40 & $28(70) \dagger$ & 0 \\
$\quad(10 \mathrm{mg} / \mathrm{kg}$ s.c.) & & & & \\
\hline
\end{tabular}

${ }^{*} P<0.001$ compared with control value ( $\chi^{2}$ with Yates' correction).

$\dagger P<0.01$ compared with value for poly I :C alone ( $\chi^{2}$ with Yates' correction).

\section{Experiment 2}

During experiments to examine whether administration of poly $\mathrm{I}: \mathrm{C}$ was associated with elevations of PGs in blood draining from the reproductive tract, it was found that anaesthesia significantly increased the sensitivity of the rabbits to poly I:C. In conscious rabbits, the $\mathrm{LD}_{50}$ was greater than $2.5 \mathrm{mg} / \mathrm{kg}$ i.v.; only 1 out of 4 rabbits died at a dose of $2.5 \mathrm{mg} / \mathrm{kg}$ i.v. and none died at lower doses. In anaesthetized animals, however, the $\mathrm{LD}_{50}$ was reduced to $0.5 \mathrm{mg} / \mathrm{kg}$ i.v. At a dose of $1 \mathrm{mg} / \mathrm{kg}$ i.v. both anaesthetized rabbits died, and 4 out of 8 rabbits died during the 6-h observation period after receiving only $0.5 \mathrm{mg}$ poly $\mathrm{I}: \mathrm{C} / \mathrm{kg}$. This is why the numbers of 
animals in Table 3 vary. One rabbit died before the first post-treatment blood sample could be withdrawn and thus is not included in the data shown in Table 3 . None of the 4 rabbits that received the same dose of poly I:C and indomethacin died during the $6 \mathrm{~h}$ experimental period. The very large increases of PGF in rabbits treated with poly I:C alone may have been implicated in the sudden deaths, which were usually characterized by tachycardia and hyperventilation followed by respiratory and cardiac arrest. Pathological examination showed intravascular haemorrhages.

In control animals, there were no significant changes in PGF or PGE (Tables 3 and 4). Poly I:C caused a significant linear elevation of PGF only during the first $2 \mathrm{~h}$; the regression coefficient calculated for all values up to $4 \mathrm{~h}$ just failed to be significant (Table 4). This was due to the large individual differences in PGF concentrations at 2 and $4 \mathrm{~h}$ (Table 3). By contrast, PGE levels in uterine vein blood were increased linearly during the first $4 \mathrm{~h}$ (Table 4). In animals given poly $\mathrm{I}: \mathrm{C}+$ indomethacin, no elevations of either PGF or PGE were observed; in fact PGF values declined linearly up to $4 \mathrm{~h}$, and PGE values showed a similar but not significant trend (Tables 3 and 4).

Table 3. Mean \pm s.e.m. concentrations $(\mathrm{ng} / \mathrm{ml})$ of PGF and PGE in uterine vein blood of anaesthetized rabbits treated with indomethacin $(10 \mathrm{mg} / \mathrm{kg} \mathrm{s.c.})$, poly I:C $(0.5 \mathrm{mg} / \mathrm{kg}$ i.v.) or both at $24 \mathrm{~h}$ after hCG injection

\begin{tabular}{lccccccc}
\hline & & \multicolumn{7}{c}{ Hours after treatment } \\
\cline { 3 - 8 } Treatment & PG & 0 & 0.5 & 1 & 2 & 4 & 6 \\
\hline Vehicle & F & $0.55 \pm 0.10$ & $0.57 \pm 0.21$ & $0.66 \pm 0.18$ & $0.56 \pm 0.16$ & $0.53 \pm 0.23$ & $0.70 \pm 0.35$ \\
& E & $0.93 \pm 0.20$ & $1.26 \pm 0.31$ & $1.41 \pm 0.21$ & $1.17 \pm 0.32$ & $1.26 \pm 0.28$ & $1.12 \pm 0.34$ \\
Poly 1:C & F & $0.82 \pm 0.29$ & $1.06 \pm 0.45$ & $1.22 \pm 0.44$ & $14.46 \pm 8.21(5)$ & $6.80 \pm 4.86(4)$ & $0.78 \pm 0.30(3)$ \\
& E & $0.98 \pm 0.18$ & $0.98 \pm 0.11(6)$ & $1.12 \pm 0.15$ & $2.78 \pm 0.70(5)$ & $2.99 \pm 1.38(4)$ & $1.45 \pm 0.44(3)$ \\
Poly I:C + & F & $0.60 \pm 0.14$ & $0.46 \pm 0.09$ & $0.50 \pm 0.10$ & $0.22 \pm 0.03$ & $0.21 \pm 0.01$ & $0.31 \pm 0.04$ \\
indo- & E & $0.44 \pm 0.17$ & $0.35 \pm 0.15$ & $0.28 \pm 0.09$ & $0.19 \pm 0.04$ & $0.17 \pm 0.05$ & $0.20 \pm 0.01$ \\
methacin & & & & & & & \\
\hline
\end{tabular}

The no. of animals in each group was 4 for the vehicle and poly $\mathrm{I}: \mathrm{C}+$ indomethacin experiments and 7 for those with poly $\mathrm{I}: \mathrm{C}$ alone, except as indicated in parentheses (see text).

Table 4. Regression analyses of PG levels in uterine vein blood versus time ( $0-4 \mathrm{~h}$ values only) in relation to drug treatment

\begin{tabular}{llcccc}
\hline \multicolumn{1}{c}{ Treatment } & PG & $\begin{array}{c}\text { No. of } \\
\text { observations }\end{array}$ & $\begin{array}{c}\text { Regression } \\
\text { coefficient }\end{array}$ & $P$ & Regression equation $\neq$ \\
\hline Vehicle & $\mathrm{F}$ & 20 & -0.06 & 0.796 & $y=0.596-0.000 x$ \\
& $\mathrm{E}$ & 20 & 0.10 & 0.665 & $y=1.150+0.000 x$ \\
Poly I : C & $\mathrm{F}$ & 30 & 0.35 & 0.058 & $y=1.063+0.041 x$ \\
& $\mathrm{~F} \dagger$ & 26 & 0.51 & $0.008^{*}$ & $y=-1.570+0.110 x$ \\
& $\mathrm{E}$ & 30 & 0.38 & $0.037^{*}$ & $y=1.169+0.009 x$ \\
& $\mathrm{E} \dagger$ & 29 & 0.55 & $0.002^{* *}$ & $y=0.853+0.010 x$ \\
Poly I: C + & $\mathrm{F}$ & 20 & -0.63 & $0.003^{* *}$ & $y=0.545-0.002 x$ \\
indomethacin & $\mathrm{E}$ & 20 & -0.41 & 0.073 & $y=0.379-0.001 x$ \\
\hline
\end{tabular}

$\dagger$ Calculated for $0-2 \mathrm{~h}$ values only. $¥$ In the regression equation, the values of $x$ are in minutes.

* Significant $(P<0.05)$ (linear regression analysis, Sokal \& Rohlf, 1969).

** Significant $(P<0.01)$ (linear regression analysis, Sokal $\&$ Rohlf, 1969).

\section{Experiment 3}

There were no significant differences in amount of PGE or PGF produced by different tissues in control animals, whether all control and treated values were compared in one test or control values were compared only between themselves (Table 5), but there was a great 
variability between animals. Similarly, although all mean values for PGE and PGF were higher in the treated than in the control animals, significant increases were only observed for endometrium. These changes were, however, very substantial, PGE release increasing 16-fold and PGF 33-fold over control. The ratios of PGF/PGE release in control and treated animals were similar, varying between 0.8 and 2.0 for myometrium, oviduct and lung, but being considerably greater for endometrium -8.1 in control and 16.5 in treated animals.

Table 5. Release of PGE and PGF ( $\mathrm{ng} / \mathrm{mg}$ protein in $1 \mathrm{~h}$ ) into the medium in vitro by tissues from control or poly I:C (1 mg/kg i.v.) treated rabbits (5/group) killed $26 \mathrm{~h}$ after hCG and $2 \mathrm{~h}$ after treatment

\begin{tabular}{lccccc}
\hline & \multicolumn{2}{c}{ Control } & \multicolumn{2}{c}{ Poly I :C } \\
\cline { 2 - 3 } \cline { 5 - 5 } \multicolumn{1}{c}{ Tissue } & PGE & PGF & & PGE & PGF \\
\hline Lung & $0.57 \pm 0.44$ & $0.60 \pm 0.34$ & & $2.73 \pm 1.36$ & $2.12 \pm 0.97$ \\
Oviduct & $0.63 \pm 0.25$ & $1.12 \pm 0.41$ & & $1.73 \pm 0.76$ & $1.82 \pm 0.43$ \\
Myometrium & $0.37 \pm 0.13$ & $0.73 \pm 0.35$ & & $4.22 \pm 2.52$ & $6.26 \pm 3.19$ \\
Endometrium & $0.98 \pm 0.34$ & $7.97 \pm 4.43$ & & $16.09 \pm 6.03^{*}$ & $265.79 \pm 67.71 \dagger$ \\
\hline
\end{tabular}

Significant differences between means were determined by Student-Newman-Kuels test (Sokal \& Rohlf, 1969).

* Significantly different $(P<0.05)$ from all other PGE values.

$\dagger$ Significantly different $(P<0.05)$ from all other PGF values.

\section{Experiment 4}

In control animals, PGs were metabolized most efficiently by lung, then by oviduct and lastly, by uterus. However, metabolism of PGF-2 $\alpha$ by oviduct and uterus did not differ

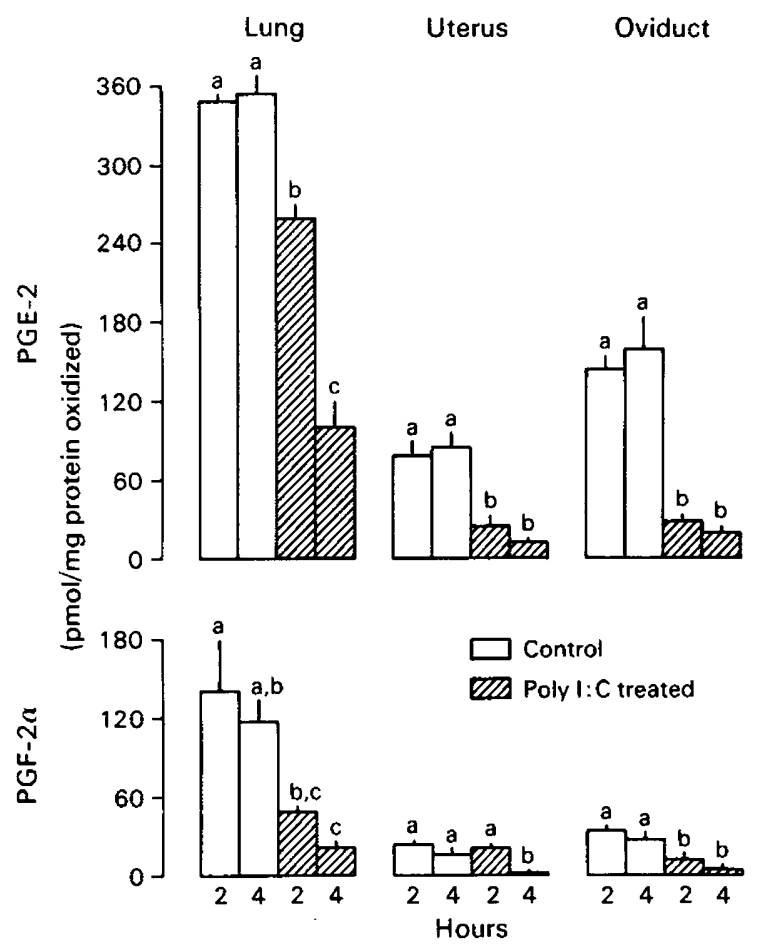

Text-fig. 1. Mean ( \pm s.e.m.) amounts of PGE-2 and PGF-2 $\alpha$ oxidized (pmol/mg protein) by rabbit tissues in relation to time after i.v. injection of vehicle or $1 \mathrm{mg}$ poly $\mathrm{I}: \mathrm{C} / \mathrm{kg}$. In each grouping significant differences $(P<0.05$, Student-Newman-Kuels test $)$ are indicated by superscripts ( $a$ is different from $b$ and $c$, but not from $a, b$, etc.). 
significantly at 2 or $4 \mathrm{~h}$. Although metabolism of PGE-2 was greater than that of PGF- $2 \alpha$ for all times, there were no differences in metabolism for each individual PG by the same tissue at the two times. After treatment with poly I:C, metabolism of both PGs was severely impaired in all tissues studied at both times (Text-fig. 1), the only exception to this being PGF-2 $\alpha$ metabolism by uterus $2 \mathrm{~h}$ after poly I:C. The degree of impairment varied with the tissues and PG substrate, but by $4 \mathrm{~h}$ after poly I:C the ability of all tissues to metabolize PGs was less than $20 \%$ of control except for PGE by lung, and even that was below 30\% (Text-fig. 2). In general, there was less 15-keto prostaglandin found in the treated than in the control groups, and most of the products of metabolism were in the form of the 13,14-dihydro-15-keto metabolites (data not shown). This suggests that the action of poly I:C was largely directed against the 15-hydroxyprostaglandin dehydrogenase enzyme, while the $\Delta^{13}$-reductase enzyme was unaffected. This appeared to be true for all tissues, both prostaglandins and both times of study.
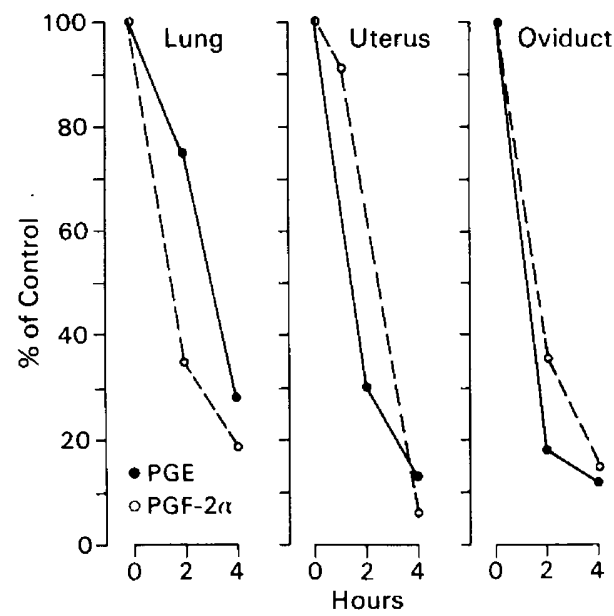

Text-fig. 2. Percentage change from control values (100\%) of metabolism of PGE-2 and PGF-2 $\alpha$ by rabbit lung, uterus and oviduct cytosol. All values are assumed to be $100 \%$ at $0 \mathrm{~h}$, which is equivalent to $24 \mathrm{~h}$ after hCG injection. The percentage changes were then calculated from the respective 2 and $4 \mathrm{~h}$ ( 26 and $28 \mathrm{~h}$ after hCG) control values. All differences from control are significant at $P<0.05$ except the $2 \mathrm{~h}$ value for PGF-2 $\alpha$ in the uterus.

\section{Discussion}

The present experiments demonstrate that poly I:C shares another action in common with endotoxin. Like endotoxin, poly I:C causes accelerated ovum transport in rabbits over a range of doses when given at $24 \mathrm{~h}$ after an ovulating injection. This action is reversible by indomethacin, an inhibitor of PG synthesis, and is associated with increased levels of PGs (E and F) emanating from the reproductive tract. The elevation of PG levels that occurs in oviductal tissue and in lung appears to be due solely to decreased ability of the tissue to metabolize PGs. The mean amounts of PGs released into the medium by the whole oviduct in the present experiments (Table 5), although more variable, are not different from that released by ampulla under similar conditions (PGE: $0.40 \pm 0.05$, PGF: $0.51 \pm 0.08 \mathrm{ng} / \mathrm{mg}$ protein $/ \mathrm{h}$ ) (Harper, Coons, Radicke, Hodgson \& Valenzuela, 1980b) or by isthmus (PGE: 0.49 \pm 0.07, PGF: $0.57 \pm 0.06$ $\mathrm{ng} / \mathrm{mg}$ protein/h) (Harper, 1979).

For the uterus the situation is more complex. In the present experiments, no attempt was made to separate myometrium and endometrium because endometria from 3 animals must be pooled to prepare an adequate amount of cytosol. However, in unpublished experiments with 
oestrous rabbits, the metabolism of PGE-2 $(83.8 \mathrm{pmol} / \mathrm{mg}$ protein $/ 15 \mathrm{~min})$ and of PGF-2 $\alpha$ $(17.2 \pm 3.6 \mathrm{pmol} / \mathrm{mg}$ protein $/ 30 \mathrm{~min})$ was greater in myometrium $(n=9)$ than in endometrium $(\mathrm{n}=3: 11.3 \pm 2.2 \mathrm{pmol} \mathrm{PGE}-2 / \mathrm{mg}$ protein $/ 15 \mathrm{~min} ; 2.4 \pm 1.7 \mathrm{pmol} \mathrm{PGF}-2 \alpha / \mathrm{mg}$ protein $/ 30$ min). Thus the myometrium contributes disproportionately to the metabolism of PGs in the whole uterus while, at least from the present control experiments, production of PGs by endometrium and myometrium does not differ. After treatment with poly $\mathrm{I}: \mathrm{C}$ endometrial, but not myometrial, production of both PGs was stimulated. At $2 \mathrm{~h}$ after poly I:C there was both increased release and decreased metabolism of PGE in these in-vitro incubations, the sum of these factors giving rise to the increased PGE levels seen in uterine vein blood at this same time (Table 3). By contrast, at $2 \mathrm{~h}$ after poly I:C, PGF metabolism by uterus was unchanged, while PGF release from endometrium was greatly increased. It would seem likely that the higher values of PGF in uterine vein blood resulted from increased synthesis. Since, at $4 \mathrm{~h}$ after poly $\mathrm{I}: \mathrm{C}, \mathrm{PG}$ levels in uterine vein blood were lower than or the same as the $2 \mathrm{~h}$ value (Table 3 ) and metabolism by whole uterus was maximally depressed, it seems probable that PG synthesis had also fallen from peak values. The present results are not directly comparable to those on the inhibition of metabolism by endotoxin (Harper, Bodkhe \& Friedrichs, 1980a), because of changed incubation conditions, but a preliminary study shows that the effects are similar.

The actions of poly $\mathrm{I}: \mathrm{C}$ therefore seem comparable to those of endotoxin, at least as far as actions on ovum transport and early pregnancy are concerned (Adamson et al., 1969; Valenzuela et al., 1978; Harper et al., 1978, 1979, 1980c; present study). Poly I:C seems as toxic relative to its actions on ovum transport as endotoxin in conscious, but not in anaesthetized, rabbits. The increased toxicity of poly $\mathrm{I}: \mathrm{C}$ following anaesthesia seems to be mediated by PGs, since this phenomenon was not observed in animals concurrently treated with indomethacin. Bito (1977) has reported that protein preparations from commercial suppliers can be contaminated by endotoxin. Four commercial protein preparations (bovine, rat and human serum albumins and ovalbumin) contained endotoxin activity equivalent to $1-11 \mathrm{ng}$ Serratia marcescens endotoxin in $10 \mathrm{mg}$ protein, i.e. $0.00001-0.0001 \%$ contamination. To explain the present results in rabbits, both for actions on ovum transport and toxicity, a $1 \%$ contamination of poly I:C with endotoxin-like activity would have to be present. Since the poly I:C preparation has been confirmed as free of endotoxin contamination, it would seem unlikely that such contamination can explain the present results.

We thank Dr John Pike (Upjohn Co.) for the gift of prostaglandins. This work was supported in part by WHO contract S77121 and NIH grants HD14048 and P30 HD10202 (Bioassay and Radioimmunoassay Cores).

\section{References}

Absher, M. \& Stinebring, W.R. (1969) Endotoxin-like properties of Poly I.Poly C, an interferon stimulator. Nature, Lond. 223, 715-717.

Adamson, R.H., Fabro, S., Homan, E.R., O'Gara, R.W. \& Zendzian, R.P. (1969) Pharmacology of polyriboinosinic:polyribocytidylic acid, a new antiviral and antitumour agent. In Antimicrobial Agents and Chemotherapy, pp. 148-152. Ed. G. L. Hobby. Amer. Soc. Microbiology, Bethesda.

Bergström, S., Dunér, H., Von Euler, U.S., Pernow, B. \& Sjövall, J. (1959) Observations on the effects of infusion of prostaglandin E in man. Acta physiol. scand. 45, 145-151.

Bito, L.Z. (1977) Inflammatory effects of endotoxin-like contaminants in commonly used protein preparations. Science, N.Y. 196, 83-85.
Bodkhe, R.R. \& Harper, M.J.K. (1979) Influence of hCG injection and steroid treatment on prostaglandin metabolism by rabbit uterus and oviduct. $J$. Reprod. Fert. 57, 101-112.

Carlson, L.A., Ekelund, L.-G. \& Orö, L. (1968) Clinical and metabolic effects of different doses of prostaglandin $\mathrm{E}_{1}$ in man. Acta med. scand. 183, 423-430.

Cornell, C.J., Jr, Smith, K.A., Cornwell, C.G., Burke, G.P. \& McIntyre, O.R. (1976) Systemic effects of intravenous polyriboinosinic-polyribocytidylic acid in man. J. Natl. Cancer Inst. 57, 1211-1216.

Field, A.K., Tytell, A.A., Lampson, G.P. \& Hilleman, M.R. (1967) Inducers of interferon and host resistance. II. Multistranded synthetic polynucleotide complexes. Proc. natn. Acad. Sci. U.S.A. 58, 1004-1010. 
Field, A.K., Young, C.W., Krakhoff, I.H., Tytell, A.A., Lampson, G.P., Nemes, M.M. \& Hilleman, M.R. (1971) Induction of interferon in human subjects by poly I:C. Proc. Soc. exp. Biol. Med. 136, 1180-1186.

Freeman, A.l., Al-Bussam, N., O'Malley, J.A., Stutzman, L., Bjornsson, S. \& Carter, W.A. (1977) Pharmacologic effects of polyinosinic - polycytidylic acid in man. J. med. Virol. 1, 79-93.

Greisman, S.E. \& Hornick, R.B. (1973) Mechanisms of endotoxin tolerance with special reference to man. $J$. Infect. Dis. 128, Suppl. S265-S276.

Guggenheim, M.A. \& Baron, S. (1977) Clinical studies of an interferon inducer, polyriboinosinic - polyribocytidylic acid [Poly (I) Poly (C)], in children. $J$. Infect. Dis. 136, 50-58.

Harper, M.J.K. (1979) Prostaglandin (PG) production by rabbit oviduct. Proc. 4th Int. Prostaglandin Conf., Washington, D.C., p. 46, Abstr.

Harper, MJ.K., Valenzuela, G. \& Hodgson, B.J. (1978) Accelerated ovum transport in rabbits induced by endotoxin. I. Changes in prostaglandin levels and reversal of endotoxin effects. Prostaglandins 15, 43-63.

Harper, M.J.K., Valenzuela, G., Hodgson, B.J. \& Siler-Khodr, T.M. (1979) Contraceptive properties of endotoxin in rabbits. Fert. Steril. 31, 441-447.

Harper, M.J.K., Bodkhe, R.R. \& Friedrichs, W.E. (1980a) Effect of endotoxin treatment on prostaglandin metabolism by rabbit uterus and oviduct. $J$. Reprod. Fert. 58, 101-108.

Harper, M.J.K., Coons, L.W., Radicke, D.A., Hodgson, B.J. \& Valenzuela, G. (1980b) Role of prostaglandins in contractile activity of the ampulla of the rabbit oviduct. Am.J. Physiol. 238, E157-166.

Harper, M.J.K., Weinberg, L., Moreno, A. \& Friedrichs, W.E. (1980c) Effects of endotoxin from different bacteria on ovum transport in rabbits. Biol. Reprod. 23, 487-494.

Hodgson, B.J. \& Pauerstein, C.J. (1976) Comparison of oviductal transport of fertilized and unfertilized ova after hCG or coitus-induced ovulation in the rabbit. Biol. Reprod. 14, 377-380.

Karim, S.M.M. \& Filshie, G.M. (1970) Therapeutic abortion using prostaglandin $\mathrm{F}_{2 \alpha}$. Lancet 1, 157-159.

Lindsay, H.L., Trown, P.W., Brandt, J. \& Forbes, M. (1969) Pyrogenicity of Poly $\mathrm{I}$. Poly $\mathrm{C}$ in rabbits. Nature, Lond. 223, 717-718.

Lowry, O.H., Rosebrough, N.J., Farr, A.L. \& Randall, R.J. (1951) Protein measurement with the Folin phenol reagent. J. biol. Chem. 193, 265-275.

Sokal, R.R. \& Rohlf, F.J. (1969) Biometry. W.H. Freeman \& Co., San Francisco, California.

Suter, E. (1964) Hyperreactivity to endotoxin in infection. In Bacterial Endotoxins, pp. 435-447. Eds M. Landy \& W. Braun. Institute of Microbiology, Rutgers University, New Brunswick.

Takehara, M. (1977) Antiviral effects of double stranded RNA from mice dwarf virus on infection of mice with western equine encephalitis virus. Microbiol. Immunol. 21, 309-315.

Valenzuela, G., Ross, H.D., Hodgson, B.J., Harper, M.J.K. \& Pauerstein, C.J. (1977) Effect of inhibitors of prostaglandin synthesis and metabolism on ovum transport in the rabbit. Fert. Steril. 28, 992-997.

Valenzuela, G., Harper, M.J.K. \& Magnasco, L. (1978) Endotoxin-induced interruption of early pregnancy in the rabbit. J. Reprod. Fert. 54, 205-207.

Yaron, M., Yaron, I., Gurari-Rotman, D., Revel, M., Lindner, H.R. \& Zor, U. (1977) Stimulation of prostaglandin $\mathrm{E}$ production in cultured human fibroblasts by Poly (I) poly(C) and human interferon. Nature, Lond. 267, 457-459.

Received 3 October 1980 